\title{
Synthesis and Investigation of Pseudo Binary System $\mathrm{CaTiSiO}_{5}-\mathrm{YFeSnO}_{5}$
}

\author{
L. H. Grigoryan'1, R. H. Grigoryan² \\ ${ }^{1}$ Federal State Institution of Science, Institute of Problems of Chemical Physics RAS, Chernogolovka, Russia \\ ${ }^{2}$ Federal State Institution of Science, Institute of Structural Macrokinetics RAS, Chernogolovka, Russia \\ Email: hrant31@icp.ac.ru
}

Received 30 October 2014; revised 29 November 2014; accepted 31 December 2014

Copyright (C) 2015 by authors and Scientific Research Publishing Inc.

This work is licensed under the Creative Commons Attribution International License (CC BY).

http://creativecommons.org/licenses/by/4.0/

cc) (i) Open Access

\begin{abstract}
The research is devoted to the multicomponent system $\mathrm{CaTiSiO}_{5}-\mathrm{YFeSnO}_{5}$. The synthesis of solid solutions $\mathrm{Ca}_{1-\mathrm{x}} \mathrm{Y}_{\mathrm{x}} \mathrm{Ti}_{1-\mathrm{x}} \mathrm{Sn}_{\mathrm{x}} \mathrm{Si}_{1-\mathrm{x}} \mathrm{Fe}_{\mathrm{x}} \mathrm{O}_{5}(\mathrm{x}=0-1.0, \Delta \mathrm{x}=0.1)$ was conducted in low-temperature plasma of hydrogen-oxygen flame. It was found that ions $\mathrm{Ca}^{2+}, \mathrm{Ti}^{4+}$ and $\mathrm{Si}^{4+}$ in the molecule of titanit may be substituted with $\mathrm{t}$ ions $\mathrm{Y}^{3+}, \mathrm{Fe}^{3+}$ and $\mathrm{Sn}^{4+}$. In this case, the system produces two phases of variable composition with broad regions of homogeneity. There were defined the boundaries of formed phases, crystallographic and electrical parameters of the solid solutions. All solid solutions have a semiconductor conductivity type, whose value is linearly dependent on the temperature and composition of the sample.
\end{abstract}

\section{Keywords}

Solid Solutions, Titanite (Sphene), Pseudobrookite, Electrical Properties, Structure

\section{Introduction}

Metal oxides containing transition elements possess unique physical properties, they are subject to numerous scientific studies and are successfully used in modern electronics. Particularly complex oxides containing delements, including oxides having the structure of sphene (titanite $\mathrm{CaTiSiO}_{5}$ ) are of great practical interest.

Synthesis and study of solid solutions with the structure of sphene containing transition elements is not only of theoretical but also of practical interest. Propensity compounds with sphene form solid solutions with wide homogeneity region containing transition elements, indicates the perspective of their application as radio materials.

Possibility of full or partial replacement of the atoms in the crystal lattice of sphene leads to a natural change in the physical properties, representing both theoretical and practical interest. It was shown possibilities to re- 
place the titanium atoms in the sphene structure with the atoms of tin [1] [2]. Gradual replacement of titanium atoms of tin atoms leads to the formation of a continuous series of solid solutions and homogeneous to a natural reduction of conductivity samples [3]. A significant change in the crystal lattice was not observed also at full replacement of silicon germanium atoms, leading to the formation of the germanium analogue of titanite $\left(\mathrm{CaTiGeO}_{5}\right)$ [4]. However it has been found that simultaneous replacement of atoms calcium and silicon with two atoms of trivalent elements such as $\mathrm{Cr}, \mathrm{Mn}, \mathrm{Fe}, \mathrm{Eu}$, etc. leads to a significant change in the lattice structure: the monoclinic crystal lattice of sphene becoming to rhombic structure, with the formation of the psedobrukit [5]-[7]. As a result, of the complete replacement of $\mathrm{Ca}^{2+}$ ions and $\mathrm{Si}^{4+}$ in sphene by ions $\mathrm{Fe}^{3+}$ and $\mathrm{Nd}^{3+}$ there was obtained the single crystal composition $\mathrm{NdFeTiO}_{5}$ [6]. The investigation of $\mathrm{CaTiSiO}_{5}-\mathrm{Fe}_{2} \mathrm{TiO}_{5}$ [7] has shown that replacing $\mathrm{Ca}^{2+}+\mathrm{Si}^{4+} \rightarrow 2 \mathrm{Fe}^{3+}$ leads to a significant increase in electrical conductivity of samples, but replacing more than $50 \%$ calcium and silicon by iron, result is the formation of solid solutions with the structure of pseudobrookite.

The present communication is devoted to the study of simultaneous heterovalent substitution of all three cations in sphene: $\mathrm{Ca}^{2+}+\mathrm{Ti}^{4+}+\mathrm{Si}^{4+} \rightarrow \mathrm{Y}^{3+}+\mathrm{Sn}^{4+}+\mathrm{Fe}^{3+}$. Simultaneous substitution of one divalent and two tetravalent (Ca, Ti, Si) atoms in a lattice of $\mathrm{CaTiSiO}_{5}$ by two trivalent and one tetravalent (Y, Fe, Sn) represents not only the theoretical but also practical interest. To solve this problem, it has been investigated previously undescribed pseudo-binary system $\mathrm{CaTiSiO}_{5}-\mathrm{YFeSnO}_{5}$. There was built the diagram of the system's state and defined the crystallographic and electrical parameters of the samples of compositions $(\mathrm{CaTiSi})_{1-\mathrm{x}}\left(\mathrm{YFeSn}_{\mathrm{x}} \mathrm{O}_{5}\right.$.

\section{Experimental Procedure}

Synthesis of solid solutions $\mathrm{Ca}_{1-\mathrm{x}} \mathrm{Y}_{\mathrm{x}} \mathrm{Ti}_{1-\mathrm{x}} \mathrm{Sn}_{\mathrm{x}} \mathrm{Si}_{1-\mathrm{x}} \mathrm{Fe}_{\mathrm{x}} \mathrm{O}_{5}(0 \leq \mathrm{x} \leq 1, \Delta \mathrm{x}=0.1)$ was carried out in parallel in the low-temperature plasma of hydrogen-oxygen flame (LP), and ceramic technology (CT) [8]. As starting substances were used the ultrapure oxides of relevant elements: $\mathrm{CaO}, \mathrm{TiO}_{2}, \mathrm{SiO}_{2}, \mathrm{Y}_{2} \mathrm{O}_{3}, \mathrm{SnO}_{2}$ and $\mathrm{Fe}_{2} \mathrm{O}_{3}$. Samples were synthesized by methods LP and TM then were heated at $1170 \mathrm{~K}$ for 6 hours followed by rapid cooling on a copper substrate. The calculations were performed using the software package [9]. The density of the samples was determined by pycnometric.

Conductivity of the samples was measured by the compensation in the air, using four silver electrodes [10]. The temperature dependence of the electrical conductivity was determined in the temperature range 293 - $900 \mathrm{~K}$. Samples for measurement were prepared from powder passed through a laboratory CO-200 sieve (63 microns) after compression to form pills $(\mathrm{d}=20 \mathrm{~mm}, \mathrm{l}=2.1 \mathrm{~mm})$ at a pressure of $400 \mathrm{MPa}$. The permittivity of the samples was measured using the flat capacitor $(20 \mathrm{~V}, 800 \mathrm{~Hz})$. Molar polarization of the sample is calculated by the equation of Clausius-Mossotti.

\section{Results and Discussion}

Comparison of x-ray diagrams of the same composition synthesized by (LP) to (CD) revealed their identity. Following is the data obtained for the samples synthesized by (NP).

Based on X-ray diagrams, it was found that in these conditions the system $\mathrm{CaTiSiO}_{5}-\mathrm{YSnFeO}_{5}$ form two phases $(\alpha$ and $\beta$ ) of variable composition with a wide homogeneous regions: $\alpha$-phase $0 \leq \mathrm{x} \leq 0.45$ and $\beta$-phase $0.70 \leq \mathrm{x} \leq 1.00$. Samples of the composition $0.45 \leq \mathrm{x} \leq 0.70$ contain two phases (Figure 1 ).

$\boldsymbol{\alpha}$-phase. Solid solutions of compositions from CaTiSiO $\mathrm{Ca}_{5}$ to $\mathrm{Ca}_{0.55} \mathrm{Y}_{0.45} \mathrm{Ti}_{0.55} \mathrm{Sn}_{0.45} \mathrm{Si}_{0.55} \mathrm{Fe}_{0.45} \mathrm{O}_{5}$ crystallize in the lattice sphene. Thus, replacement of up to $45 \%$ of the ions $\mathrm{Ca}^{2+}, \mathrm{Ti}^{4+}$ and $\mathrm{Si}^{4+}$ ions on the $\mathrm{Y}^{3+}, \mathrm{Sn}^{4+}$ and $\mathrm{Fe}^{3+}$ did not result in a significant rearrangement of the crystal lattice sphene (Table 1). As seen from the data intoduction of ions $\mathrm{Y}^{3+}, \mathrm{Sn}^{4+}$ and $\mathrm{Fe}^{3+}$ ions instead of $\mathrm{Ca}^{2+}, \mathrm{Ti}^{4+}$ and $\mathrm{Si}^{4+}$ in the $\alpha$-phase leads to a significant increase in the unit cell parameters. However, as can been expected, the densities of obtained solid solutions are also growing (Figure 2).

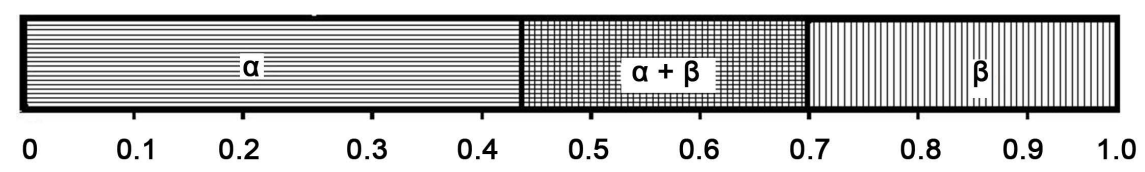

Figure 1. Phase composition of $\mathrm{Ca}_{1-\mathrm{x}} \mathrm{Ti}_{1-\mathrm{x}} \mathrm{Sn}_{\mathrm{X}} \mathrm{Si}_{1-\mathrm{x}} \mathrm{Y}_{\mathrm{X}} \mathrm{Fe}_{\mathrm{x}} \mathrm{O}_{5}$ system. 


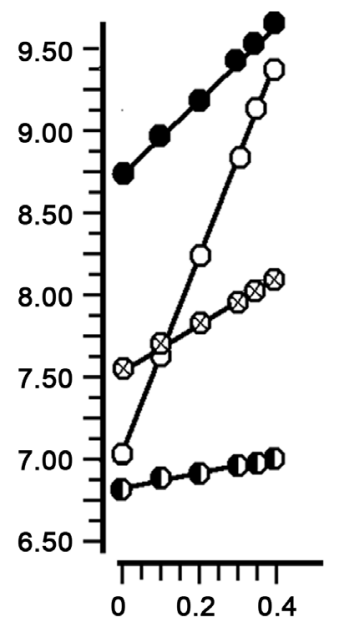

Figure 2. Dependence of the unit cell parameters (a-O, b- , c- - ) and the density (d-D) of solid solutions of $\alpha$-phase system $\mathrm{Ca}_{1-\mathrm{x}} \mathrm{Ti}_{1-\mathrm{x}} \mathrm{Sn}_{\mathrm{x}} \mathrm{Si}_{1-\mathrm{x}} \mathrm{Y}_{\mathrm{x}} \mathrm{Fe}_{\mathrm{x}} \mathrm{O}_{5}$ from the composition.

Table 1. Characteristics of unit cell of solid solutions of $\alpha$-phase system $\mathrm{CaTiSiO}_{5}-\mathrm{YFeSnO}_{5}$.

\begin{tabular}{ccccccc}
\hline Composition & $\mathrm{a} \pm 0.01, \AA$ & $\mathrm{B} \pm 0.01, \AA$ & $\mathrm{C} \pm 0.01, \AA$ & $\beta \pm 0.1$ & $\begin{array}{c}\mathrm{d}_{\text {X-ray }} \\
\left(\mathrm{g} / \mathrm{cm}^{-3}\right)\end{array}$ & $\begin{array}{c}\mathrm{d}_{\text {pycnom }} \\
\left(\mathrm{g} / \mathrm{cm}^{-3}\right)\end{array}$ \\
\hline $\mathrm{CaTiSiO}_{5}$ & $7.061^{1)}$ & $8.710^{1)}$ & $6.568^{1)}$ & $113.86^{2)}$ & 3.524 & 3.48 \\
$\mathrm{Ca}_{0.9} \mathrm{Ti}_{0.9} \mathrm{Sn}_{0.1} \mathrm{Si}_{0.9} \mathrm{Y}_{0.1} \mathrm{Fe}_{0.1} \mathrm{O}_{5}$ & 7.61 & 8.93 & 6.69 & 113.8 & 3.731 & 3.68 \\
$\mathrm{Ca}_{0.8} \mathrm{Ti}_{0.8} \mathrm{Sn}_{0.2} \mathrm{Si}_{0.8} \mathrm{Y}_{0.2} \mathrm{Fe}_{0.2} \mathrm{O}_{5}$ & 8.15 & 9.14 & 6.80 & 113.8 & 3.906 & 3.89 \\
$\mathrm{Ca}_{0.7} \mathrm{Ti}_{0.7} \mathrm{Sn}_{0.3} \mathrm{Si}_{0.7} \mathrm{Y}_{0.3} \mathrm{Fe}_{0.3} \mathrm{O}_{5}$ & 8.72 & 9.33 & 6.91 & 113.8 & 4.065 & 4.04 \\
$\mathrm{Ca}_{0.6} \mathrm{Ti}_{0.6} \mathrm{Sn}_{0.4} \mathrm{Si}_{0.6} \mathrm{Y}_{0.4} \mathrm{Fe}_{0.4} \mathrm{O}_{5}$ & 9.28 & 9.58 & 7.03 & 113.8 & 4.196 & 4.15 \\
$\mathrm{Ca}_{0.55} \mathrm{Ti}_{0.55} \mathrm{Sn}_{0.45} \mathrm{Si}_{0.55} \mathrm{Y}_{0.45} \mathrm{Fe}_{0.45}$ & 9.51 & 9.71 & 7.09 & 113.8 & 4.216 & 4.17 \\
\hline
\end{tabular}

${ }^{1)} \pm 0.005 ;{ }^{2} \pm 0.02$.

Input $\mathrm{Y}^{3+}$ ions occupy seven vertex polyhedral voids that were previously occupied by ions $\mathrm{Ca}^{2+}$. The radii of these ions differ little from each other: $\mathrm{r}(\mathrm{Y})=0.116 \mathrm{~nm}, \mathrm{r}(\mathrm{Ca})=0.130 \mathrm{~nm}$ [11]. Such substitution also contributes to the similarity of the electron shells of these ions: $3 s^{2} 3 \mathrm{p}^{6}\left(\mathrm{Ca}^{2+}\right)$ and $4 \mathrm{~s}^{2} 4 \mathrm{p}^{6}\left(\mathrm{Y}^{3+}\right)$. A Fe ${ }^{3+}$ ions, thus, occupy tetrahedral interstices previously occupied by ions $\mathrm{Si}^{4+}$.

Despite the greater tendency of $\mathrm{Fe}^{3+}$ ions to occupy the octahedral interstices, There are numerous examples where the $\mathrm{Fe}^{3+}$ ions are in tetrahedral cavities oxygen environment such as in the crystal lattice of $\mathrm{Fe}_{3} \mathrm{O}_{4}$ where in the tetrahedral voids occupied $1 / 3$ of the ions $\mathrm{Fe}^{3+}[12]$. As a result, even replacement of $45 \%$ of calcium ions and silicon in the $\alpha$-phase does not result in significant changes in the lattice of sphene. As the authors of [13], belonging of the sphene to the lower-monoclinic system is a consequence of the presence of calcium ions in the lattice, occupying polyhedral (semivershinnye) voids formed by distorted octahedra $\mathrm{TiO}_{6}$. As a result, even replacement of $45 \%$ of calcium ions and silicon in the $\alpha$-phase does not result in significant changes in the lattice of sphene. Hence, we expect that the replacement of ions $\mathrm{Ca}^{2+}$ on the $\mathrm{Y}^{3+}$ ions will lead to the gradual streamlining lattice, turning seven deformed lattice to the octahedral polyhedral. In fact, samples containing more than 70 at \% Yttrium forms a crystal lattice of higher symmetry.

$\boldsymbol{\beta}$-phase. When administered 55 at $\%$ and more ions $\mathrm{Y}^{3+}, \mathrm{Fe}^{3+}$ and $\mathrm{Sn}^{4+}$, instead of $\mathrm{Ca}^{2+}, \mathrm{Si}^{4+}$ and $\mathrm{Ti}^{4+}$ solid solutions crystallize in the orthorhombic symmetry in lattice of the psevdobrookit. The border of the homogeneity of $\beta$-phase extends in the region $\mathrm{x}=0.70-1.0$, which corresponds to the composition of

$\mathrm{Ca}_{0.30} \mathrm{Y}_{0.70} \mathrm{Ti}_{0.30} \mathrm{Sn}_{0.70} \mathrm{Si}_{0.30} \mathrm{Fe}_{0.70} \mathrm{O}_{5}-\mathrm{YFeTiO}_{5}$.

The value of the lattice parameters of solid solutions of $\beta$-phase are shown in Table 2. Like the $\alpha$-phase values of the elementary cells of solid solutions, as well as their densities are in the substantially rectilinear function of the composition (Figure 3). 


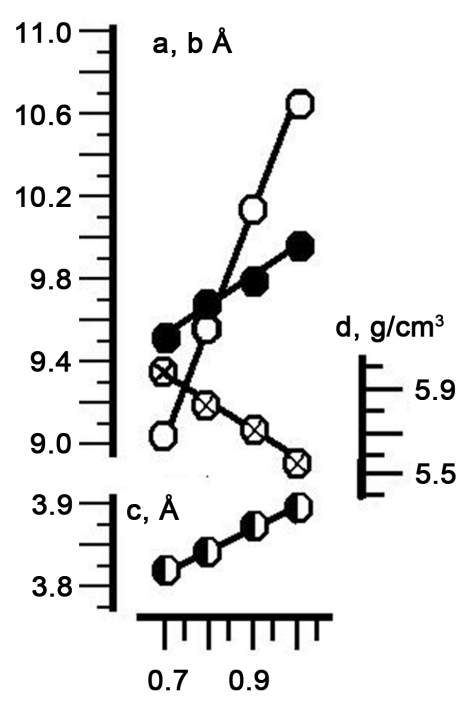

Figure 3. The dependence of cell parameters (a-O, b-e c- c- and the density (d-D) of solid solution of $\beta$-phase system $\mathrm{Ca}_{1-\mathrm{x}} \mathrm{Ti}_{1-\mathrm{x}} \mathrm{Sn}_{\mathrm{x}} \mathrm{Si}_{1-\mathrm{X}} \mathrm{Y}_{\mathrm{X}} \mathrm{Fe}_{\mathrm{x}} \mathrm{O}_{5}$ from the composition.

Table 2. Characteristics of unit cell of solid solutions of $\beta$-phase system $\mathrm{CaTiSiO}_{5}-\mathrm{YFeSnO}_{5}$.

\begin{tabular}{cccccc}
\hline Composition & $\mathrm{a} \pm 0.01 ; \AA$ & $\mathrm{b} \pm 0.01 ; \AA$ & $\mathrm{c} \pm 0.01 ; \AA$ & $\mathrm{d}_{\mathrm{X} \text {-ray }}\left(\mathrm{g} / \mathrm{cm}^{-3}\right)$ & $\mathrm{d}_{\text {pycnom }}\left(\mathrm{g} / \mathrm{cm}^{-3}\right)$ \\
\hline $\mathrm{Ca}_{0.3} \mathrm{Ti}_{0.3} \mathrm{Sn}_{0.7} \mathrm{Si}_{0.3} \mathrm{Y}_{0.7} \mathrm{Fe}_{0.7} \mathrm{O}_{5}$ & 9.14 & 9.52 & 3.83 & 5.962 & 5.48 \\
$\mathrm{Ca}_{0.2} \mathrm{Ti}_{0.2} \mathrm{Sn}_{0.8} \mathrm{Si}_{0.2} \mathrm{Y}_{0.8} \mathrm{Fe}_{0.8} \mathrm{O}_{5}$ & 9.64 & 9.65 & 3.85 & 5.821 & 5.50 \\
$\mathrm{Ca}_{0.1} \mathrm{Ti}_{0.1} \mathrm{Sn}_{0.9} \mathrm{Si}_{0.1} \mathrm{Y}_{0.9} \mathrm{Fe}_{0.9} \mathrm{O}_{5}$ & 10.13 & 9.78 & 3.87 & 5.693 & 5.49 \\
$\mathrm{YFeSnO}_{5}$ & $10.742^{1)}$ & $9.925^{1)}$ & $3.878^{1)}$ & 5.554 & 5.35 \\
\hline
\end{tabular}

${ }^{1)} \pm 0.005$.

As in the $\alpha$-phase the increase of the value of " $\mathrm{x}$ " in the $\beta$-phase leads to an increase in cell volume. However, the transition from the monoclinic to the rhombohedral structure observed abrupt decrease in cell volume (Figure 4). In contrast to the $\alpha$-phase, increasingthe ion content $\mathrm{Y}^{3+}, \mathrm{Fe}^{3+}$ and $\mathrm{Sn}^{4+}$ in the $\beta$-phase leads to a noticeable increase in the lattice parameters.

The synthesized solid solutions both $\alpha$ - and $\beta$-phases, are dielektriks with character of semiconductor conductivity. The determination results of conductivity, dielectric constant, the band gap, the molar polarizability and polarization of the synthesized solid solutions are shown in Table 3.

As can be seen from the data presented in Table 3, the introduction of tin, yttrium, and iron (p-, d-, and delements) in substituting calcium, silicon, and titanium (s-, p-and d-elements) leads to narrowing of the band gap and improves the conductivity of the solid solutions. Dielectric constant and band gap samples thus reduced. Increased content of yttrium, tin and iron leads to an increase in the values of the molar polarization of samples in areas of both phases. Simultaneously, there is a sharp, abrupt decrease in these parameters during the transition phase $(\alpha \rightarrow \beta)$, which is due to a sharp decrease in cell volume and an increase in density of the samples in the transition phase. Concentration dependences of the all parameters are linear in the fields of both phases (Figure 5).

\section{Conclusion}

The multicomponent system $\mathrm{CaTiSiO}_{5}-\mathrm{YFeSnO}_{5}$ was the subject of the research. It was found that ions $\mathrm{Ca}^{2+}$, $\mathrm{Ti}^{4+}$ and $\mathrm{Si}^{4+}$ in the molecule of titanit can be substituted with ions $\mathrm{Y}^{3+}, \mathrm{Fe}^{3+}$ and $\mathrm{Sn}^{4+}$ which leads to the formation of two phases of compositions $\mathrm{Ca}_{1_{-\mathrm{x}}} \mathrm{Y}_{\mathrm{x}} \mathrm{Ti}_{1_{-\mathrm{x}}} \mathrm{Sn}_{\mathrm{x}} \mathrm{Si}_{1_{-\mathrm{x}}} \mathrm{Fe}_{\mathrm{x}} \mathrm{O}_{5}$ with broad regions of homogeneity. There were defined the boundaries of the uniform phases at $1170 \mathrm{~K}$. The samples $\alpha$-phase $(\mathrm{x}=0.0-0.45)$ crystallize in the structure of titanite. Samples $\beta$-phase $(\mathrm{x}=0.70-1.0)$ crystallize in the orthorhombic crystal system structure 


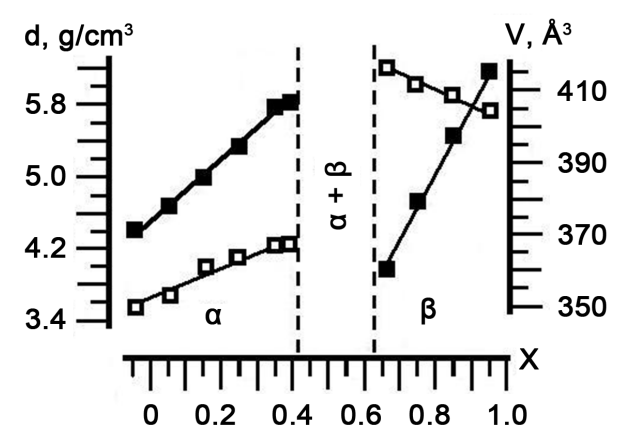

Figure 4. Dependence of the density of solid solutions (d- $\square$ ) and the unit cell volume ( $\boldsymbol{\square})$ of $\alpha$ - and $\beta$-phases system $\mathrm{Ca}_{1-\mathrm{x}} \mathrm{Ti}_{1-\mathrm{X}} \mathrm{Sn}_{\mathrm{X}} \mathrm{Si}_{1-\mathrm{x}} \mathrm{Y}_{\mathrm{X}} \mathrm{Fe}_{\mathrm{X}} \mathrm{O}_{5}$.

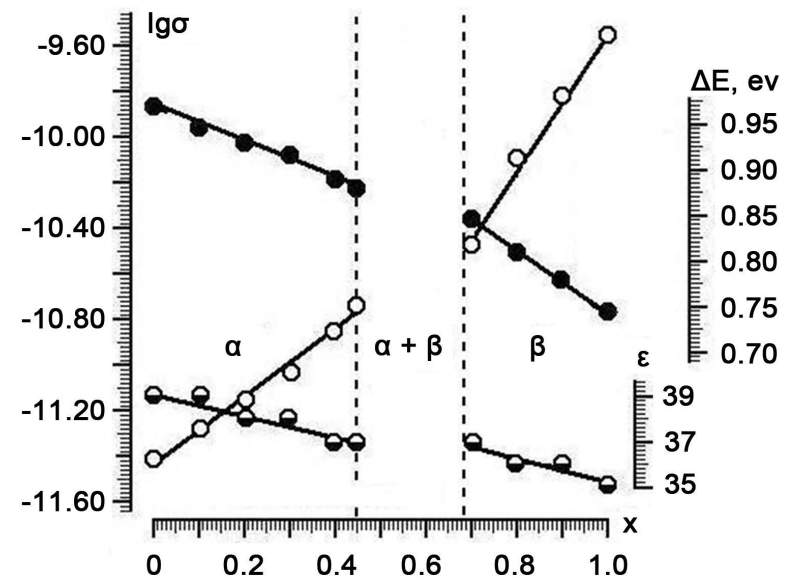

Figure 5. Dependence of specific conductivity $\left({ }^{\circ}\right)$, dielectric capacitivity $(\bullet)$ and the band gap (-) of solid solutions $\mathrm{Ca}_{1-\mathrm{x}} \mathrm{Ti}_{1-\mathrm{x}} \mathrm{Sn}_{\mathrm{X}} \mathrm{Si}_{1-\mathrm{X}} \mathrm{Y}_{\mathrm{X}} \mathrm{Fe}_{\mathrm{x}} \mathrm{O}_{5}$ from the composition.

Table 3. Values of specific conductivity $(\sigma)$.dielectric capacitivity $(\varepsilon)$. band gap $(\Delta \mathrm{E})$ and molar polarization $(\mathrm{P})$ of solid solutions $\mathrm{Ca}_{1-\mathrm{x}} \mathrm{Ti}_{1-\mathrm{x}} \mathrm{Sn}_{\mathrm{x}} \mathrm{Si}_{1-\mathrm{x}} \mathrm{Y}_{\mathrm{x}} \mathrm{Fe}_{\mathrm{x}} \mathrm{O}_{5}$.

\begin{tabular}{ccccc}
\hline & $\sigma, \mathrm{om}^{-1} \cdot \mathrm{cm}^{-1}$ & $\varepsilon$ & $\Delta \mathrm{E}, \mathrm{eV}$ & $\mathrm{P}, \mathrm{cm}^{3}$ \\
\hline $\mathrm{CaTiSiO}_{5}$ & $\alpha$-phase & & & \\
\hline $\mathrm{Ca}_{0.9} \mathrm{Ti}_{0.9} \mathrm{Sn}_{0.1} \mathrm{Si}_{0.9} \mathrm{Y}_{0.1} \mathrm{Fe}_{0.1} \mathrm{O}_{5}$ & $3.802 \times 10^{-12}$ & 39 & 0.973 & 51.62 \\
$\mathrm{Ca}_{0.7} \mathrm{Ti}_{0.7} \mathrm{Sn}_{0.3} \mathrm{Si}_{0.7} \mathrm{Y}_{0.3} \mathrm{Fe}_{0.3} \mathrm{O}_{5}$ & $5.470 \times 10^{-12}$ & 39 & 0.951 & 52.37 \\
$\mathrm{Ca}_{0.6} \mathrm{Ti}_{0.6} \mathrm{Sn}_{0.4} \mathrm{Si}_{0.6} \mathrm{Y}_{0.4} \mathrm{Fe}_{0.4} \mathrm{O}_{5}$ & $9.528 \times 10^{-12}$ & 38 & 0.922 & 54.68 \\
$\mathrm{Ca}_{0.55} \mathrm{Ti}_{0.55} \mathrm{Sn}_{0.45} \mathrm{Si}_{0.55} \mathrm{Y}_{0.45} \mathrm{Fe}_{0.45}$ & $1.439 \times 10^{-11}$ & 37 & 0.900 & 56.10 \\
& $1.820 \times 10^{-11}$ & 37 & 0.884 & 57.41 \\
\hline $\mathrm{Ca}_{0.3} \mathrm{Ti}_{0.3} \mathrm{Sn}_{0.7} \mathrm{Si}_{0.3} \mathrm{Y}_{0.7} \mathrm{Fe}_{0.7} \mathrm{O}_{5}$ & & & & 46.33 \\
$\mathrm{Ca}_{0.2} \mathrm{Ti}_{0.2} \mathrm{Sn}_{0.8} \mathrm{Si}_{0.2} \mathrm{Y}_{0.8} \mathrm{Fe}_{0.8} \mathrm{O}_{5}$ & $2.52 \times 10^{-11}$ & 37 & 0.873 & 49.79 \\
$\mathrm{Ca}_{0.1} \mathrm{Ti}_{0.1} \mathrm{Sn}_{0.9} \mathrm{Si}_{0.1} \mathrm{Y}_{0.9} \mathrm{Fe}_{0.9} \mathrm{O}_{5}$ & $7.907 \times 10^{-11}$ & 37 & 0.833 & 493 \\
$\mathrm{YFeSnO}_{5}$ & $1.517 \times 10^{-10}$ & 36 & 0.782 & 53.18 \\
\hline
\end{tabular}

pseudobrookite. The electrical properties of solid solutions formed were also investigated. All samples are insulators with a semiconductor character of electrical conductivity. Complete replacement of the ions $\mathrm{Ca}^{2+}, \mathrm{Ti}^{4+}$ and $\mathrm{Si}^{4+}$ increases the conductivity of the samples by a factor of two. 


\section{References}

[1] Takenouchi, S. (1971) Hydrothermal Synthesis and Consideration of Genesis of Malayaite. Journal of Mineralium Deposita, 6, 335-347.

[2] Hollanbaugh, C.L. and Rosenberg, P.E. (1983) Substition of Ti for Si in Titanite and New and Member Cell Dimension for Titanit. American Mineralogist, 68, 177-180.

[3] Grigoryan, R.A. and Grigoryan, L.A. (2007) The Syntheses and Investigation of the System $\mathrm{CaTiSiO}_{5}-\mathrm{CaSnSiO}_{5}$. Chemical Journal of Armenia, 60, 290-293.

[4] Robbins, C.R. (1968) Synthetic $\mathrm{CaTiSiO}_{5}$ and Its Germanium Analogue $\left(\mathrm{CaTiGeO}_{5}\right)$. Materials Research Bulletin, 3, 693-698.

[5] Schurer, P.J. and Morrish, A.H. (1977) ${ }^{57}$ Fe Mössbauer Studies of AtiRO . Physical Review, 16, 951-959.

[6] Yaeger, I. (1978) Crystal Growth and Magnetic Properties of $\mathrm{NdFeTiO}_{5}$. Materials Research Bulletin, 13, 819-825. http://dx.doi.org/10.1016/0025-5408(78)90045-4

[7] Grigoryan, R.A. and Grigoryan, L.A. (2011) Synthesis and Properties of CaTiSiFeO Solid Solutions $\mathrm{Ca}_{1-\mathrm{x}} \mathrm{TiSi}_{1_{-\mathrm{x}}} \mathrm{Fe}_{2 \mathrm{x}} \mathrm{O}_{5}$. Inorganic Materials, 47, 417-419.

[8] Grigorian, R.A., Grigoryan, L.A. and Babayan, G.G. (2001) Synthesis of Solid Solutions Based on Ortotsirkonata and Zinc Ferrite. Inorganic Materials, 37, 367-370.

[9] Burnham, C.W. (1991) Least-Squares Refinement of Crystallographic Lattice Parameters for IBMPC/XT/AT and Compatibles. Harvard University, Cambridge, 24 p.

[10] Pavlov, L.P. (1987) Methods for Measuring the Parameters of Semiconductor Materials. Higher School, 239 p.

[11] Bugaenko, L.T., Ryabykh, S. and Bugaenko, A.L. (2008) Almost Complete System of Secondary Ionic Crystallographic Radii and Its Use for Determining the Ionization Potentials. Bulletin of Moscow University, 49, 363-384.

[12] Wells, A.F. (1987) Structural Inorganic Chemistry. Part 2, 324.

[13] Speer, J.A. and Gibbs, G.V. (1976) The Crystal Structure of Synthetic Titanite, $\mathrm{CaTiOSiO}_{4}$, and the Domain Texture of Natural Titanite. American Mineralogist, 61, 238-247. 
Scientific Research Publishing (SCIRP) is one of the largest Open Access journal publishers. It is currently publishing more than 200 open access, online, peer-reviewed journals covering a wide range of academic disciplines. SCIRP serves the worldwide academic communities and contributes to the progress and application of science with its publication.

Other selected journals from SCIRP are listed as below. Submit your manuscript to us via either submit@scirp.org or Online Submission Portal.
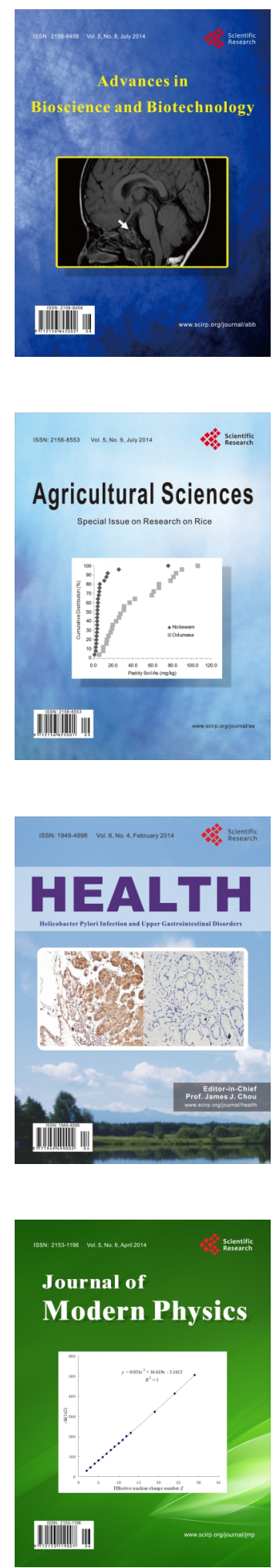
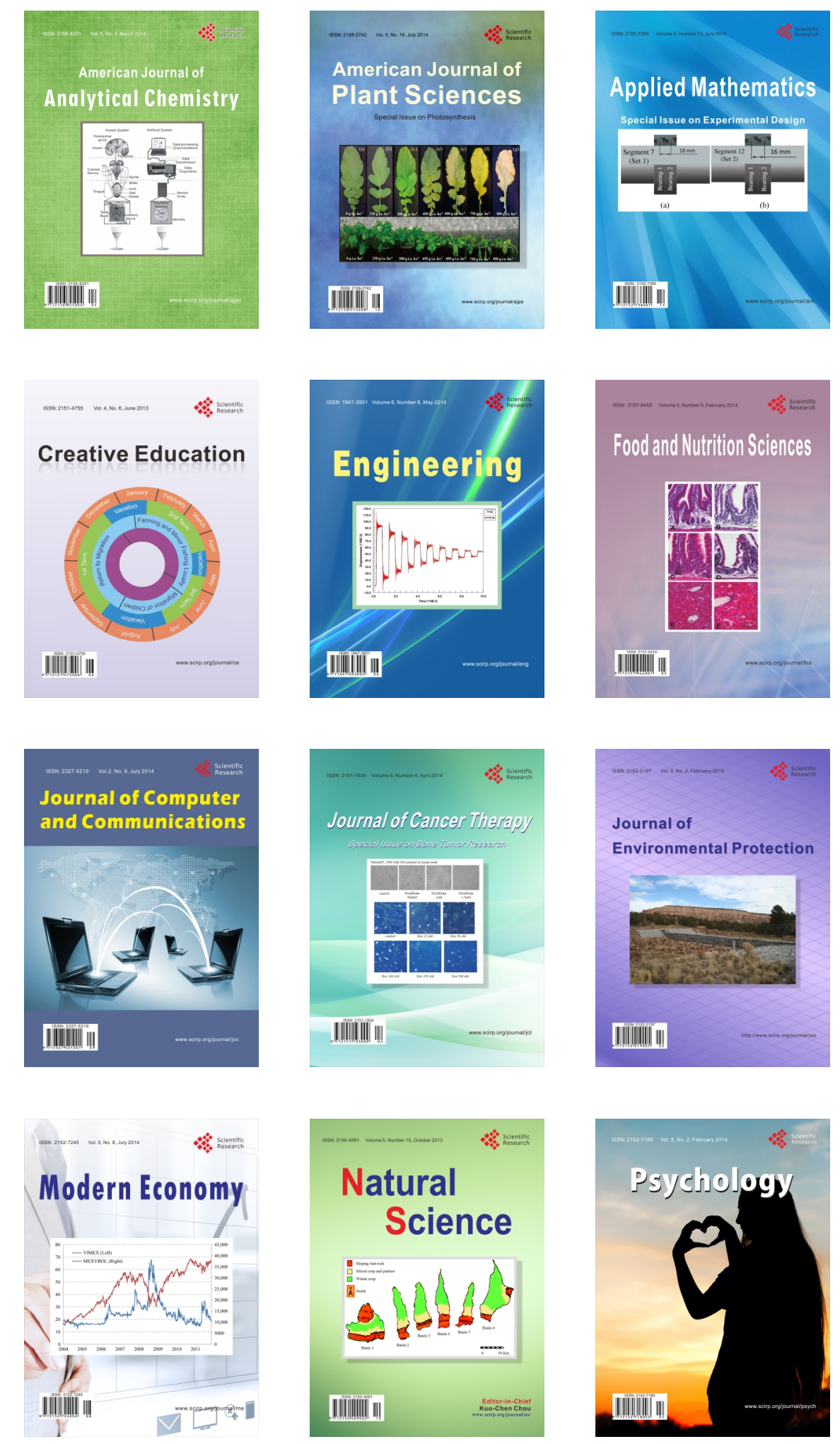